\title{
Driver's Knowledge About the Use of Drug and Traffic Accident in Riau Indonesia
}

\author{
Syamza Madya Jannati ${ }^{1}$, Agung Endro Nugroho ${ }^{2}$, Probosuseno ${ }^{3} \&$ Susi Ari Kristina ${ }^{2}$ \\ ${ }^{1}$ Clinical Pharmacy Graduate Program, Faculty of Pharmacy, Universitas Gadjah Mada, Yogyakarta, Indonesia \\ ${ }^{2}$ Faculty of Pharmacy, Universitas Gadjah Mada, Yogyakarta, Indonesia \\ ${ }^{3}$ Faculty of Medicine, Public Health, and Nursing, Universitas Gadjah Mada, Yogyakarta, Indonesia \\ Correspondence: Susi Ari Kristina, Faculty of Pharmacy, Universitas Gadjah Mada, Indonesia. E-mail: \\ susiari_k@ugm.ac.id
}

Received: August 19, 2018 Accepted: September 10, 2018 Online Published: September 12, 2018

doi:10.5539/gjhs.v10n10p113 URL: https://doi.org/10.5539/gjhs.v10n10p113

\begin{abstract}
Our study aimed to investigate the influence of socio-demographic, knowledge, attitude, toward the change in driving behavior. This research was conducted with cross-sectional study design, during the period of December 2016 until April 2017. The research instrument used was a questionnaire from Driving Under the Influence of Drugs, Alcohol, and Medicines (DRUID) project with modification. The descriptive statistics and logistic regression analysis was used. Our research revealed that from 100 respondents, about $10 \%$ male was available to change to reported behavior in frequency driving than female. About $11 \%$ of respondents aged 35-67 years old decided to change in frequency driving. Approximately $14 \%$ of respondents with higher education level were changing in reported behavior of frequency driving. Reported behavior in frequency driving was influenced by information received from health care providers and attitude about the consequences of driving under the influence of impairing medicines factors (p-value 0.006 and 0.028 ). Changing reported behavior in frequency driving can be predicted by information received from health care providers and attitudes. In the future, we need to build effective communication and ensuring patients receive information about driving-impairing medicines.
\end{abstract}

Keywords: medicines, knowledge, attitudes, behavior

\section{Introduction}

Motor vehicle crashes become an important cause of morbidity and mortality in developed and developing countries (Vearrier et al., 2016). Road accidents burden public health and economic affected either high and middle-income countries (World Health Organization, 2015).

Approximately 1.2 million people kills per year on the world's road. Road accidents considered the leading cause of death globally, with more sustaining physical pain injuries and living with impaired quality of life (World Healt Organization, 2015). Statistic data of traffic accidents in Riau amount of 1,400 events within the year of 2016. According to POLDA Riau, approximately 31 traffic accidents caused by alcohol and drugs in 2016 (POLDA Riau, 2016).

Amongst the numerous risk factors (speed, alcohol, take on a cell phone, road infrastructure) (Verster, Monique, Leufken, \& Vermeeren, 2009; Verstraete, Legrand, Vandam, Hughes, \& Griffiths, 2014; Wartatmo \& Kuschitawati, 2011), the effect of medicinal drugs has yet getting good-enough of attention (Orriols et al., 2009). To date, there are no global or regional estimates of deaths resulting from drug-impairing medicines, nor is the prevalence of them known. However, growing recognition of the problem of drug-impairing medicines has led to increased focus on this area among road safety policy-makers and researchers (World Health Organization, 2015).

Various studies found that medicinal drugs affected driver's cognition, concentration, and other essential driving skills and may put patients at increased risk for road accidents (National Highway Traffic Safety Administration, 2003). Specific drugs include alcohol, barbiturates, and methamphetamine cause alterations in driving behavior. It can disrupt concentration, perceptual functioning, and motor skills, as well as in driving control (Alonso, Pastor, Montoro, \& Esteban, 2015).

Several methods were used to study driving under the influence of drugs, consisted of experimental and 
epidemiological studies. In experimental studies, the drugs used in the study was administered in different doses to volunteers and the effects on performance were measured and compared with those resulting from administration of a placebo or a positive control. The volunteer's performance can be evaluated using tests. These assess various psychomotor and cognitive functions, tests in a driving simulator or 'real' driving tests (Verstraete et al., 2014). Prevalence of tested positive one or more psychoactive medication causes injured drivers was $21.9 \%$. The drugs were taken from whole blood and oral fluids $(n=5401)$. On case group (injured drivers, $n=96)$, the substances most often found were alcohol (11.5\%), an illicit stimulant such as amphetamines and cocaine $(9.4 \%)$ and benzodiazepines (7.3\%) (Bogstrand, Gjerde, Normann, Rossow, \& Ekeberg, 2012).

The theory of planned behavior (TPB) as a theoretical framework was widely used to predict driver behavior. TPB proposed three constructs namely attitudes, subjective norm, and perceived behavioral control. These constructs are determined by three belief based or indirect measures namely; behavioral beliefs, normative beliefs and control beliefs (Monteiro SP et al., 2012). Behavioral beliefs are the antecedent of attitude and deals with the consequences of the act. Normative beliefs and control belief were developed by subjective norm and perceived behavioral control. Each component within the model describes different constructs and should correlate more strongly with intention than with each other. The personal intention is a central factor to perform an evaluated behavior. The higher the intention to engage in an evaluated behavior (Ajzen F, 1991).In this study, knowledge and attitudes towards driving under the influence of medicines, were used to predict reported behavior in terms of change in driving.

Our study aimed to investigate the relationship between socio-demographic, knowledge, attitude toward driving under influence of medicines, toward the change in driving behavior.

\section{Methods}

\subsection{Study Design}

This research design was a cross-sectional analytical study (cross-sectional) which was conducted in Riau Province, Indonesia. The research instrument used was a questionnaire modified from Driving Under the Influence of Drugs, Alcohol, and Medicines (DRUID) project (European Monitoring Centre for Drugs and Drug Addiction (EMCDDA), 2015). The sample size was 5 to 10 times the independent variables studied. In this research, there were five independent variables so that the sample size was 35-70 subjects. Participants of this study involved 18-75 years old, use of driving impairing medicines (sedatives, antidepressants, and the first generation of antihistamines), and use of motorized vehicles. This study was approved by Medical and Health Research Ethical Committee, Faculty of Medicine, Gadjah Mada University with approval number KF/FK/1177/EC/2016.

\subsection{Questionnaire}

DRUID instrument was the questionnaire developed in the English language. The questionnaire was translated into the Indonesian language and then was reverse translation back into the English language aimed to ensure consistency between the translations. The questionnaire consisted of 43 questions, with 39 closed and 4 open questions. The questionnaire have six types of questions, consists of general information (gender, age, level of education, current living status), participation in traffic (modes of transportation, driving licenses, types of transport), medicines in traffic (use of medicines regarding the ability to drive, negative effects of medicines, factors cause of road accidents), use of medicines (prescribed medicines, experience side effects), information about medicines (possible influence medicines on ability to drive, type of medicines, sources information of medicines, attitude towards behavior in traffic (opinion regarding some statements behavior in traffic and change behavior in frequency of driving).

\subsection{Dependent Variable}

Reported behavior about change in their frequency of driving was analyzed in terms of a "no or yes". Statements on changes in frequency of driving consist of "I did not think the information was relevant to me", "It was not feasible for me to change my frequency of driving", "I did not notice any negative effects that influence my driving ability and thus frequency of driving", "other reasons", with "no" response, and "yes" response on questions "I decided not to drive a motorized vehicle anymore", "I decided to drive/ride a motorized vehicle less often", "I decided to drive/ride a motorized vehicle on less parts of the day" or "other reasons".

\subsection{Independent Variables}

Knowledge about medicines in traffic was assessed by using 5 -scale parameter $(5=$ totally agree, $4=$ agree, $3=$ no option, 2 = disagree, and 1 = totally disagree), driver could agree (or disagree) with the following sentences: "the risk of having a traffic accident is smaller when you have just started taking a driving-impairing medicine 
compared to long-term treatment", "the risk of having a traffic accident is similar when you take more of a driving-impairing medicine than prescribed", "the risk of having a road accident may increase when you combine a driving-impairing medicine and over the counter medicines (e.g. pain killers, cough remedy)", "the risk of having a road accident increases when you use alcohol while taking a driving-impairing medicine", "the risk of having a traffic accident remains the same when you use several driving-impairing medicines at the same time", "the risk of having a road accident increases with a high dose of a driving-impairing medicine".

Patient attitudes defined as feelings towards driving under the influence of medicines. A 5 -scale parameter $(5=$ totally agree, 4 = agree, $3=$ no option, $2=$ disagree, and $1=$ totally disagree) was used to analyze driver's opinion in relation to the use of impairing medicines and driving. Attitude about the consequences of driving under the influence of impairing medicines was assessed by 5 -likert scale $(5=$ totally agree; $4=$ agree; $3=$ no option; $2=$ disagree; and $1=$ totally disagree). Attitude was classified as good attitude if mean score was more than 3 , while poor attitude if mean score $\leq 3$ (Monteiro SP et al., 2012).

\subsection{Data Analysis}

Descriptive analysis was used to report on subjects characteristics such as gender, age, and educational level. Multiple linear regression analysis was used to identify patient knowledge and attitudes about driving while using medicines that might impair driving ability.

\section{Results}

\subsection{Respondents' Characteristics}

This study involved 100 drivers who use medicine causing driving ability impairment. Of this research, socio-demographic characteristic of all of the participants this research was divided three sub-characteristics, i.e. gender, age, and educational level (Table 1). Most of the participants were male (73\%). Additionally, participants with age ranged from $35-44$ were the majority (32\%). Higher general education of educational level was also the most percentage of patients (32\%). The frequent users of medicine were also the higher (95\%). All of the patients use of driving-impairing medicines, there were $36 \%$ of the use of 2 medicines. The types of medicine commonly used by participants were sedatives, antidepressants, and first generation antihistamines with $47 \%$ of patients using sedatives and antidepressants (Figure 1). Around $15 \%$ of patients had experienced side effect. The experienced side effects were sleepiness, problem concentrating, blurred view, and dizziness. The patients were obtained drug information from health care providers (39\%) and by patient self (83\%).

Table 1. Characteristics of the respondents

\begin{tabular}{llc}
\hline Characteristics & & $\begin{array}{c}\text { Percentage } \\
(\mathbf{N}=\mathbf{1 0 0}) \mathbf{\%}\end{array}$ \\
\hline Gender & & 73 \\
& Male & 27 \\
\hline Age category & Female & 11 \\
(years old) & $18-25$ & 18 \\
& $26-34$ & 32 \\
& $35-44$ & 23 \\
& $45-54$ & 13 \\
\hline Educational level & $55-64$ & 3 \\
\hline Use of motorized vehicles & $65-75$ & 2 \\
& Not completed primary education & 12 \\
\hline & Completed primary education & 27 \\
& Lower general education & 32
\end{tabular}




\begin{tabular}{|c|c|c|}
\hline \multirow[t]{6}{*}{ Use of driving-impairing medicines } & Use of 1 medicine & 10 \\
\hline & Use of 2 medicines & 36 \\
\hline & Use of 3 medicines & 34 \\
\hline & Use of 4 medicines & 12 \\
\hline & Use of 5 medicines & 7 \\
\hline & Use of 6 medicines & 1 \\
\hline \multirow[t]{4}{*}{ Prescribed medicines } & Sedatives & 37 \\
\hline & Antidepressants & 15 \\
\hline & Antihistamines $1^{\text {st }}$ generation & 1 \\
\hline & Sedatives + antidepressants & 47 \\
\hline \multirow[t]{2}{*}{ Experienced side effect } & No & 85 \\
\hline & Yes & 15 \\
\hline \multirow[t]{2}{*}{ Information received from health care providers } & No & 61 \\
\hline & Yes & 39 \\
\hline \multirow[t]{2}{*}{ Information searched by patients } & No & 17 \\
\hline & Yes & 83 \\
\hline \multirow[t]{2}{*}{ Knowledge about medicines in traffic } & Poor & 44 \\
\hline & Good & 56 \\
\hline \multirow{2}{*}{$\begin{array}{l}\text { Attitude about the use of impairing medicines and } \\
\text { driving }\end{array}$} & Poor & 35 \\
\hline & Good & 65 \\
\hline \multirow{2}{*}{$\begin{array}{l}\text { Attitude about the consequences of driving under } \\
\text { the influence of impairing medicines }\end{array}$} & Poor & 54 \\
\hline & Good & 46 \\
\hline \multirow{2}{*}{$\begin{array}{l}\text { Reported behavior about change in the frequency } \\
\text { of driving }\end{array}$} & No & 85 \\
\hline & Yes & 15 \\
\hline \multirow{2}{*}{$\begin{array}{l}\text { Reported behavior about change in the use of } \\
\text { driving-impairing medicines }\end{array}$} & No & 99 \\
\hline & Yes & 1 \\
\hline
\end{tabular}

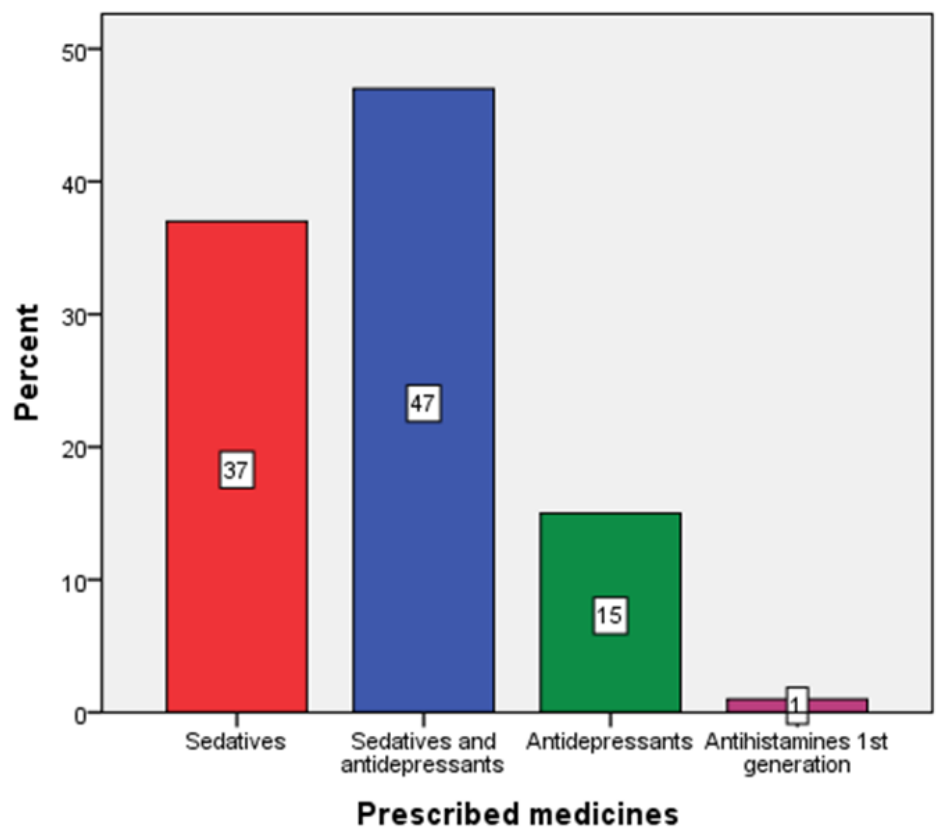

Figure 1. Prescribed medicines consumed 


\subsection{Attitude, Knowledge, and Reported Behavior toward the Use of Impairing Medicines and Driving}

Patient who had good attitude toward the use of impairing medicines and driving was approximately $65 \%$. Meanwhile, the patient had good attitude regarding consequences of driving under the influence of impairing medicines was lower $46 \%$ (Table 2). Patient had good knowledge about the risk of having a road accident when using medicines, approximately $56 \%$. About $85 \%$ of patients decided not to change the frequency of driving.

Table 2. Changing in reported behavior, concerning driving ability and use of driving-impairing medicines

\section{Reported behavior}

Changes in frequency of driving $(\mathrm{N}=100)$

\section{Patient decided not to change frequency of driving because}

I did not think the information was relevant to me $18 \quad$ No: 85

It was not feasible for me to change my frequency of driving

\section{Patient decided to change frequency of driving because}

I decided not to drive a motorized vehicle anymore

I decided to drive/ride a motorized vehicle less often

I decided to drive/ride a motorized vehicle on less parts of the day

Changes in the use of driving-impairing medicines $(\mathrm{N}=100)$

Patient decided not to change the use of driving-impairing medicines because

I did not think the information was relevant to me $93 \quad$ No: 99

There was no alternative medicine available

Other reason

5

\section{Patient decided to change the use of driving-impairing medicines because}

I decided to use (most of) the medicine at night instead of during the day

\subsection{Relationship Between Respondent Characteristics and Driving Behavior}

This research investigates the relationship between independent variables and dependent variable. Reported behavior in frequency of driving is organized as a dependent variable. A p-value $<0.05$ is marked on independent variables such as information received from health care providers and attitude about the consequences of driving under the influence of impairing medicines, 0.003 and 0.021 respectively (Table 3 ).

Table 3. Relationship socio-demographic characteristic, use of motorized vehicles, use of impairing medicines, prescribed medicines, experienced side effect, information, attitude, and knowledge toward reported behavior in frequency driving

\begin{tabular}{|c|c|c|c|}
\hline \multirow[t]{2}{*}{ Variable } & \multicolumn{2}{|c|}{$\begin{array}{l}\text { Reported behavior in frequency driving } \\
(\mathrm{N}=100) \%\end{array}$} & \multirow[t]{2}{*}{ p-value } \\
\hline & Yes & No & \\
\hline \multicolumn{4}{|l|}{ Gender } \\
\hline Male & 10 & 63 & 0.549 \\
\hline Female & 5 & 22 & \\
\hline \multicolumn{4}{|c|}{ Age category } \\
\hline $18-34$ & 4 & 25 & 0.829 \\
\hline $35-67$ & 11 & 60 & \\
\hline
\end{tabular}




\section{Educational level}

Not completed primary education - completed primary education $\quad 14$

Lower general education, higher general education-higher 1

vocational training, college or university

\begin{tabular}{|c|c|c|c|}
\hline \multicolumn{4}{|l|}{ Use of motorized vehicles } \\
\hline Sporadic users & 2 & 3 & 0.108 \\
\hline Frequent users & 13 & 82 & \\
\hline \multicolumn{4}{|l|}{ Use of driving-impairing medicines } \\
\hline Use of $1-3$ medicines & 10 & 70 & 0.161 \\
\hline Use of $4-6$ medicines & 5 & 15 & \\
\hline \multicolumn{4}{|l|}{ Prescribed medicines } \\
\hline Sedatives or antidepressants or antihistamines $1^{\text {st }}$ generation & 6 & 47 & 0.274 \\
\hline Sedatives and antidepressants & 9 & 38 & \\
\hline \multicolumn{4}{|l|}{ Experienced side effect } \\
\hline Yes & 4 & 11 & 0.170 \\
\hline No & 11 & 74 & \\
\hline \multicolumn{4}{|l|}{ Information received from health care providers } \\
\hline Yes & 11 & 28 & $0.003^{*}$ \\
\hline No & 4 & 57 & \\
\hline \multicolumn{4}{|l|}{ Information searched by driver } \\
\hline Yes & 11 & 72 & 0.280 \\
\hline No & 4 & 13 & \\
\hline \multicolumn{4}{|c|}{ Knowledge $^{b}$ about the risk of having a road accident when using medicines } \\
\hline Good & 9 & 47 & 0.735 \\
\hline Poor & 6 & 38 & \\
\hline \multicolumn{4}{|l|}{ Attitude $^{b}$ about the use of impairing medicines and driving } \\
\hline Good & 12 & 53 & 0.186 \\
\hline Poor & 3 & 32 & \\
\hline
\end{tabular}

On Table 4, variable of information received from health care providers was only as predictors for the patient behavior with p-value 0.003 . Meanwhile, other factors of predictors for reported behavior in frequency driving were gender, use of driving-impairing medicines, prescribed medicines, information searched by patient self, and knowledge about the risk of having a road accident when using medicines have no correlation. Differentiate predictor factors on independent variables showed $13.1 \%$ (adjusted $\mathrm{R}^{2}$ ). 
Table 4. Predictors for patient's reported behavior in frequency driving: multiple linear regression analysis

\begin{tabular}{ll}
\hline $\begin{array}{l}\text { Predictors for reported behavior in } \\
\text { frequency driving }\end{array}$ & $\begin{array}{l}\text { Reported behavior in frequency driving } \\
\mathbf{N}=\mathbf{1 0 0}) \%\end{array}$ \\
\hline $\begin{array}{l}\text { Independent variables } \\
\text { Constant }\end{array}$ & $\begin{array}{l}\text { Standardized coefficients (p-value) } \\
0.293\end{array}$ \\
\hline Gender & $-0.029(0.774)$ \\
$(0=$ male; $1=$ female $)$ & $0.007(0.947)$ \\
\hline $\begin{array}{l}\text { Age category } \\
(0=18-34 ; 1=35-67)\end{array}$
\end{tabular}

\section{Educational level}

$(0=$ Not completed primary education-completed primary education; $1=$ Lower general education, higher general education-higher vocational $0.052(0.615)$ training, college or university)

\section{Use of motorized vehicles}

$(0=$ Sporadic users; $1=$ Frequent users $)$

$0.195(0.054)$

Use of driving-impairing medicines

( $0=$ Use of $1-3$ medicines; $1=$ Use of $4-6$ medicines $)$

$-0.139(0.147)$

\section{Prescribed medicines}

$\left(0=\right.$ Sedatives or antidepressants or antihistamines $1^{\text {st }}$ generation; $1=-0.101(0.330)$

Sedatives and antidepressants)

\section{Experienced side effect}

$(0=$ side effect; $1=$ no side effect $)$

$0.154(0.117)$

\begin{tabular}{ll}
\hline Information received from health care providers & $0.300(0.003)^{*}$ \\
$(0=$ information was received; $1=$ information was not received $)$ &
\end{tabular}

\begin{tabular}{ll}
\hline Information searched by patient self & $-0.093(0.351)$ \\
$(0=$ information was searched; $1=$ information was not searched $)$ &
\end{tabular}
Knowledge about the risk of having a road accident when using medicines
$(0=$ good; 1 = poor $)$

\begin{tabular}{ll}
\hline Attitude about the use of impairing medicines and driving & $0.070(0.561)$ \\
$(0=$ good; $1=$ poor $)$ &
\end{tabular}

\begin{tabular}{ll}
\hline $\begin{array}{l}\text { Attitude about the consequences of driving under the influence of } \\
\text { impairing medicines }\end{array}$ & $0.185(0.040)$ \\
$(0=$ good; $1=$ poor $)$ & \\
\hline Adjusted $\mathbf{R}^{2}$ & 0.131 \\
F & 2.248 \\
p-value (model) & $<0.001^{*}$ \\
\hline
\end{tabular}

Patient's knowledge had no correlation with a change in frequency driving ( $\mathrm{p}$-value $>0.05)$. Patient's knowledge about the risk of having a road accident when using medicines has a tendency 0.825 times $(\mathrm{OR}=0.825)$ to decide not change in frequency driving. The patient received information from healthcare providers and patient's attitude regarding consequences of driving under the influence of impairing medicines have a tendency to decided change in frequency driving, respectively 0.179 times and 0.255 times $(\mathrm{OR}=0.179$ and 0.255 ; Table 5). 
Table 5. Correlation independent variables with change in driving frequency

\begin{tabular}{|c|c|c|c|c|c|}
\hline \multirow{3}{*}{ Independent variables } & \multicolumn{5}{|c|}{ Change in driving frequency $(\mathrm{N}=100)$} \\
\hline & \multirow{2}{*}{ p-value } & \multirow{2}{*}{ Constant } & \multirow{2}{*}{ Odds-ratio } & \multicolumn{2}{|c|}{$95 \% \mathrm{Cl}$ for $\mathrm{OR}$} \\
\hline & & & & lower & upper \\
\hline $\begin{array}{l}\text { Gender } \\
(0=\text { male; } 1=\text { female })\end{array}$ & 0.550 & -1.482 & 0.698 & 0.215 & 2.269 \\
\hline $\begin{array}{l}\text { Age category } \\
(0=18-34 ; 1=35-67)\end{array}$ & 0.829 & -1.696 & 0.873 & 0.254 & 3.003 \\
\hline $\begin{array}{l}\text { Educational level } \\
(0=\text { Not completed primary education-completed primary } \\
\text { education; } 1 \text { = Lower general education, higher general } \\
\text { education- higher vocational training, college or } \\
\text { university) }\end{array}$ & 0.390 & -1.638 & 0.396 & 0.048 & 3.273 \\
\hline $\begin{array}{l}\text { Use of motorized vehicles } \\
(0=\text { Sporadic users; } 1 \text { = Frequent users })\end{array}$ & 0.135 & -1.842 & 4.205 & 0.640 & 27.625 \\
\hline $\begin{array}{l}\text { Use of driving-impairing medicines } \\
(0=\text { Use of } 1-3 \text { medicines; } 1=\text { Use of } 4-6 \text { medicines })\end{array}$ & 0.170 & -1.099 & 0.429 & 0.128 & 1.437 \\
\hline $\begin{array}{l}\text { Prescribed medicines } \\
\left(0=\text { Sedatives or antidepressants or antihistamines } 1^{\text {st }}\right. \\
\text { generation; } 1=\text { Sedatives and antidepressants })\end{array}$ & 0.279 & -1.440 & 0.539 & 0.176 & 1.649 \\
\hline $\begin{array}{l}\text { Experienced side effect } \\
(0=\text { no side effect; } 1=\text { side effect })\end{array}$ & 0.180 & -1.012 & 0.409 & 0.111 & 1.512 \\
\hline $\begin{array}{l}\text { Information received from health care providers } \\
(0=\text { information was not received; } 1=\text { information was } \\
\text { received })\end{array}$ & $0.006^{*}$ & -0.934 & 0.179 & 0.502 & 0.611 \\
\hline $\begin{array}{l}\text { Information searched by patient self } \\
(0=\text { information was not searched; } 1=\text { information was } \\
\text { searched })\end{array}$ & 0.287 & -1.879 & 2.014 & 0.556 & 7.300 \\
\hline $\begin{array}{l}\text { Knowledge about the risk of having a road accident } \\
\text { when using medicines } \\
(0=\text { poor; } 1 \text { = good })\end{array}$ & 0.735 & -1.653 & 0.825 & 0.270 & 2.522 \\
\hline $\begin{array}{l}\text { Attitude about the use of impairing medicines and } \\
\text { driving } \\
(0=\text { poor; } 1=\text { good })\end{array}$ & 0.197 & -1.485 & 0.414 & 0.109 & 1.580 \\
\hline $\begin{array}{l}\text { Attitude about the consequences of driving under the } \\
\text { influence of impairing medicines } \\
(0=\text { poor; } 1=\text { good })\end{array}$ & $0.028 *$ & -1.157 & 0.255 & 0.075 & 0.865 \\
\hline
\end{tabular}

\section{Discussion}

The current study examined the predictors of change behavior in driving. This research is the first study conducted to explore the variables related to changed behavior in driving in Indonesia. Socio-demographic, use of vehicles, use of driving-impairing medicines, experienced side effect, and information searched by patient self, attitude about the use of impairing medicines and driving, and knowledge about the risk of having a road accident when using medicines are not significant association with the reported behavior in frequency driving. Our study found that knowledge is not as the predictor for reported behavior in frequency driving. In addition, $85 \%$ of patient 
decided not to change the frequency of driving. Only $9 \%$ of $56 \%$ good knowledge be having patient decided to change in frequency driving. Our study also highlights that information received from health care providers and attitude about the consequences of driving under the influence of impairing medicines were able to change in frequency driving.

A similar trend was found in the study conducted in Nigeria, providing useful information increased on the knowledge $(\mathrm{p}<0.05)$ and attitude $(\mathrm{p}<0.001)$ towards road traffic and safety codes among commercial motorcyclists (Adog \& Ilika, 2006). Other research in Italy and Saudi Arabia showed that teacher has an important role a regard to education on road safety toward students` knowledge and behavior (Miccoli, Giraldi, Boccia, \& La Torre, 2012; Ramisetty-Miklera \& Almakadma, 2016). Generally, the patient' knowledge about medicines and side effect is received from communication with their general practitioner (Cullen, Kelly, \& Murray, 2006). However, it is expected that reported behavior in frequency driving is not always influenced by the same range of variables, but also a combination of different factors (Monteiro et al., 2012).

According to Monteiro et al. (2012) patients who experienced side effects and who have a negative attitude towards driving under the influence of impairing medicines are more prone to change their driving frequency behaviour (Monteiro et al., 2012). Moreover, in Mirzaei et al. study (2014), it was described that the higher scores in attitude, the more impact on decreasing the road traffic crashes. The patient's attitude about the consequences of driving under the influence of impairing medicines can influence decision-making in the amount of $11 \%$ of $46 \%$ good attitude to change in frequency driving (Mirzaei et al., 2014).

This research highlights the importance of building effective communication and ensuring the patient to receive the information about medicines causing driving impairment. Alonso, et al. (2015) said that it was very important built an inter-professional collaboration between doctors, pharmacists, government and pharmaceutical companies in order to enhance community awareness in these types of medicines (Alonso et al., 2015). Another study suggests that health professionals are not sufficiently informing their patients of the risks posed by potentially driver impairing (PDI) medications. Increased knowledge, awareness, and education would modify their behavior to reduce risks (MacLennan, Owsley, \& McGwin, 2009). Patients have expected more information on all aspects drug information of their healthcare. Furthermore increased patient information and education will lead to a reduction in the side effect of driving under impairing drug.

We observed that on the variables of information received from health care providers and attitudes are able to change the decision of frequency driving. A future research to campaigns intensively about communicating with the patient on medicine which might cause harm in driving should be prioritized.

\section{Conclusions}

Our study revealed that information received from health care providers and attitude about the consequences of driving under the influence of impairing medicines are predictors for patient's reported behavior in frequency driving. Our study calls for a strategic intervention plan to change the driving behavior through a structured program in community and clinical settings. Multilevel and multifaceted interventions may hold great promise in reducing unintended road accidents and changing the culture as a whole.

\section{Acknowledgements}

This work was supported by the Faculty of Pharmacy grant. We would like to thank the surveyors for data collection process.

\section{Competing Interests Statement}

The authors have no conflicts of interest associated with the material in this paper.

\section{References}

Adog, O. U., \& Ilika, A. L. (2006). Knowledge of and attitude towards road traffic codes among commercial motorcycle riders in Anambra State. The Nigerian Postgraduate Medical Journal, 13(4), 297-300.

Ajzen, F. (1991). The Theory of Planned Behavior. Organizational Behavior, and Human Decision Processes, 50, 179-211. https://doi.org/10.1016/0749-5978(91)90020-T

Alonso, F., Pastor, J. C., Montoro, L., \& Esteban, C. (2015). Driving under the influence of alcohol: Frequency, reasons, perceived risk and punishment. Substance Abuse Treatment, Prevention, and Policy, 10(11), 1-9. https://doi.org/10.1186/s13011-015-0007-4

Bogstrand, S. T., Gjerde, H., Normann, P. T., Rossow, I., \& Ekeberg, Ø. (2012). Alcohol, psychoactive substances and non-fatal road traffic accidents - a case-control study. BMC Public Health, 12(734). 
https://doi.org/10.1186/1471-2458-12-734

Cullen, G., Kelly, E., \& Murray, F. E. (2006). Patients' knowledge of adverse reactions to current medications. Br J Clin Pharmacol, 62(2), 232-236. https://doi.org/10.1111/j.1365-2125.2006.02642.x

European Monitoring Centre for Drugs and Drug Addiction (EMCDDA). (2015). Project DRUID (Driving under the Influence of Drugs, Alcohol and Medicines).

MacLennan, P. A., Owsley, C. R. L., \& McGwin, G. (Eds.). (2009). Older Adult's Knowledge about Medications That Can Impact Driving. Washington DC: AAA foundation for traffic safety.

Miccoli, S., Giraldi, G., Boccia, A., \& La Torre, G. (2012). School teacher's knowledge, attitudes and behaviors towards road safety: Results from a multicenter cross-sectional study in Italy. Medicina Preventiva e di Comunità, 24(4), 289-299.

Mirzaei, R., Hafezi-Nejad, N., Sabagh, M. S., Moghaddam, A. A., Eslami, V., \& Rakhshani, F. (2014). Dominant role of driver's attitude in prevention of road traffic crashes: A study on knowledge, attitude, and practice of drivers in Iran. Accid Anal Prev, 66, 36-42. https://doi.org/10.1016/j.aap.2014.01.013

Monteiro, S. P., van Dijk, L., Verstraete, A. G., Álvarez, F. J., Heissing, M., \& de Gier, J. J. (2012). Predictors for patient knowledge and reported behaviour regarding driving under the influence of medicines: a multi-country survey. BMC Public Health, 12(59). https://doi.org/10.1186/1471-2458-12-59

National Highway Traffic Safety Administration. (2003). State of Knowledge of Drug-Impaired Driving.

Orriols, L., Salmi, L. R., Philip, P., Moore, N., Delorme, B., \& Castot, A. (2009). The impact of medicinal drugs on traffic safety: A systematic review of epidemiological studies. Pharmacoepidemiol Drug Saf, 18, 647-658. https://doi.org/10.1002/pds. 1763

POLDA Riau. (2016). Laporan Kecelakaan 2016. Pekanbaru: POLDA Riau.

Ramisetty-Miklera, S., \& Almakadma, A. (2016). Attitudes and behaviors towards risky driving among adolescents in Saudi Arabia. International Journal of Pediatrics and Adolescent Medicine, 3(2), 56-63. https://doi.org/10.1016/j.ijpam.2016.03.003

Vearrier, D., Vearrier, L., McKeever, R., Okaneku, J., LaSala, G., \& Goldberger, D. (2016). Issues in driving impairment. Dis Mon, 62, 72-116. https://doi.org/10.1016/j.disamonth.2016.02.002

Verster, J. C., Monique, A. J., Leufken, M. R. M., \& Vermeeren, A. (2009). Insomnia, hypnotic drugs and traffic safety. Drugs, Driving and Traffic Safety, 233-244. https://doi.org/10.1007/978-3-7643-9923-8_14

Verstraete AG, Legrand SA, Vandam L, Hughes B, \& Griffiths P (Eds.). (2014). Drug use, impaired driving and traffic accidents (Vol. 2, 2nd ed.). Luxembourg: EMCDDA.

Wartatmo, S. H., \& Kuschitawati, S. (2011). Pengendara sebagai Faktor Risiko Terjadinya Kecelakaan Lalu Lintas Sepeda Motor Tahun 2010. Berita Kesehatan Masyarakat, 27(2).

World Health Organization [WHO]. (2015). WHO Global Status Report on Road Safety.

\section{Copyrights}

Copyright for this article is retained by the author(s), with first publication rights granted to the journal.

This is an open-access article distributed under the terms and conditions of the Creative Commons Attribution license (http://creativecommons.org/licenses/by/4.0/). 